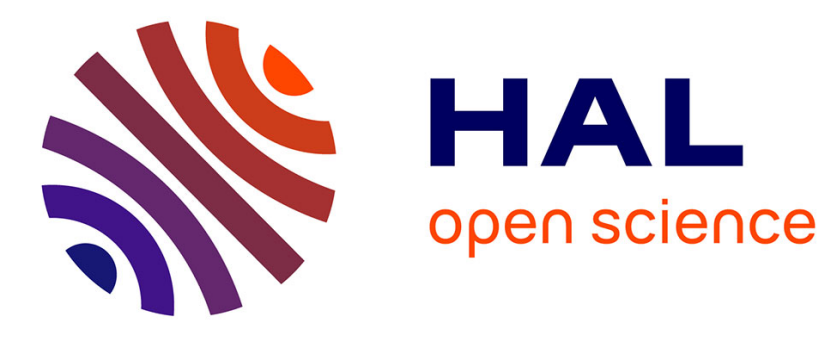

\title{
Childhood bullying as a predictor for becoming a teenage mother in Finland
}

Venla Lehti, Andre Sourander, Anat Klomek, Solja Niemelä, Lauri Sillanmäki, Jorma Piha, Kirsti Kumpulainen, Tuula Tamminen, Irma Moilanen, Fredrik Almqvist

\section{To cite this version:}

Venla Lehti, Andre Sourander, Anat Klomek, Solja Niemelä, Lauri Sillanmäki, et al.. Childhood bullying as a predictor for becoming a teenage mother in Finland. European Child and Adolescent Psychiatry, 2010, 20 (1), pp.49-55. 10.1007/s00787-010-0147-z . hal-00649052

\section{HAL Id: hal-00649052 https://hal.science/hal-00649052}

Submitted on 7 Dec 2011

HAL is a multi-disciplinary open access archive for the deposit and dissemination of scientific research documents, whether they are published or not. The documents may come from teaching and research institutions in France or abroad, or from public or private research centers.
L'archive ouverte pluridisciplinaire HAL, est destinée au dépôt et à la diffusion de documents scientifiques de niveau recherche, publiés ou non, émanant des établissements d'enseignement et de recherche français ou étrangers, des laboratoires publics ou privés. 


\section{$\underline{\text { Title }}$}

Childhood bullying as a predictor for becoming a teenage mother in Finland

\section{Authors}

Venla Lehti, MD, Department of Child Psychiatry, University of Turku, Finland

Andre Sourander, MD, PhD, Professor, Department of Child Psychiatry, University of Turku, Finland

Anat Klomek, PhD, Lecturer, New School of Psychology, Interdisciplinary Center (IDC), Herzliya, Israel; Assistant

Professor, Division of Child and Adolescent Psychiatry, Columbia University, New York, United States

Solja Niemelä, MD, PhD, Department of Psychiatry, University of Turku, Finland

Lauri Sillanmäki, Department of Child Psychiatry, University of Turku, Finland

Jorma Piha, MD, PhD, Professor, Department of Child Psychiatry, University of Turku, Finland

Kirsti Kumpulainen, MD, PhD, Professor, Department of Child Psychiatry, University of Kuopio, Finland

Tuula Tamminen, MD, PhD, Professor, Department of Child Psychiatry, University of Tampere, Finland

Irma Moilanen, MD, PhD, Professor, Department of Child Psychiatry, University of Oulu, Finland

Fredrik Almqvist, MD, PhD, Professor, Department of Child Psychiatry, University of Helsinki, Finland

\section{Contact information for the corresponding author}

Dr. Venla Lehti

E-mail: venla.lehti@utu.fi

Address: Department of Child Psychiatry, University of Turku, P.O. Box 52, 20521 Turku, Finland

Tel: + 358503061767

\section{$\underline{\text { Abstract }}$}

Objective: To examine the association between bullying behaviour at the age of eight and becoming a mother under the age of 20 .

Study design: Birth cohort study, which included 2867 Finnish girls at baseline in 1989. Register-based follow-up data on births was collected from 1994 until 2000. Information on both the main exposure and outcome was available for 2507 girls.

Results: Both bullies and victims had an increased risk of becoming a teenage mother independently of family-related risk factors. When controlled for childhood psychopathology, however, the association remained significant for bullies

(OR 2.2, $95 \%$ CI 1.2-4.1) and bully-victims (OR 1.8, $95 \%$ CI 1.05-3.2), but not for pure victims. Reports of bullying and victimization from the girls themselves, their parents and their teachers were all associated with becoming a teenage mother independently of each other.

Conclusion: There is a predictive association between being a bully in childhood and becoming a mother in adolescence. It may be useful to target bullies for teenage pregnancy prevention.

\section{Keywords}

teen pregnancy, bully, victim, risk factor, epidemiology 


\section{$\underline{\text { Introduction }}$}

Becoming a teenage mother in Western societies is a phenomenon often associated with various psychosocial problems. The socioeconomic status of teenage mothers is on average lower compared with older mothers [1,2]. Both teenage mothers [1,3-5] and their children [1,6-8] have an increased risk of mental health problems. Children of teenage mothers are more likely to be involved with delinquent behaviour [6,7] and to have problems in school [1,6,7]. They also have a higher risk of teenage pregnancy [9] and motherhood [10], themselves.

Several studies have been conducted on the factors associated with teenage pregnancy. There is evidence of low socioeconomic status, broken family structure, unsuccessful bonding between parent and child and other family factors $[11,12]$, as well as of psychiatric determinants such as conduct problems and other externalising symptoms [2,9,13-19]. In addition, a low level of education and educational expectations, as well as a dislike of school, are known to be associated with teenage pregnancy [11]. Underwood et al. suggested that controversial peer status in school is associated with becoming a teenage mother [20]. In another study, however, peer status groups did not differ from each other in this respect[17].

A school- and peer-related factor, which has not been examined previously in relation to becoming a teenage mother, is bullying. The most widely accepted definition for bullying is the one by Olweus [21]: A person is bullied when he or she is exposed, repeatedly and over time, to negative actions on the part of one or more persons. The universality and harmfulness of bullying have been widely recognised. Population-based studies indicate that 20 to $30 \%$ of school children are frequently involved in bullying as bullies and/or victims [22-26]. Bullies and victims of bullying are more likely than other children to suffer from a wide variety of problems, including depression and anxiety [27,28], low selfregard, [29] and violent behaviour [30]. Moreover, bullying behaviour during childhood is related to future psychiatric problems [21,24,31]. Previous studies have suggested that bully-victims are the most troubled in terms of outcomes $[24,31,32]$.

The aim of the present study is to examine whether bullying others or being a victim of bullying during childhood is associated with becoming a mother in adolescence. If an association does indeed exist, then the further aims are to test 1) whether it can be explained by psychiatric symptoms or by risk factors related to family background, 2) whether it is 
stronger among girls who are bullies, victims of bullying, or those who are both and 3) whether its strength varies according to the informant of bullying (teacher, parent and child).

\section{Methods}

The study is a part of the "Finnish 1981 Birth Cohort Study", a multicentre child psychiatric study in Finland. The baseline assessment was conducted in 1989, and the register data for the follow-up were collected from 1994 to 2000. Informed consent was obtained from the children's parents at baseline. The way in which the combined information from questionnaires and register data was analysed did not allow identification of the subjects. The Ethics Committee of the Intermunicipal Hospital District of Southwest Finland approved the research plan.

\section{$\underline{\text { Participants }}$}

The original study sample was drawn from the total population of Finnish children born in 1981 (n = 60,007). It consisted of 6017 children, which was $10 \%$ of the basic population. Of the selected 6017 children, 5813 (96.6\%) took part in the study in 1989. The number of female participants was 2867. Almqvist et al. [33] have previously presented the design and subjects of this study and shown that the sample is nationally representative. At follow-up, the girls in the cohort were identified by linking their personal identification number with the data in the Finnish Hospital Discharge Register. Of the 2867 girls studied in 1989, information about both bullying in childhood and births under the age of 20 was obtained for $2507(87.4 \%)$.

\section{$\underline{\text { Assessment at age eight }}$}

Data collection at baseline was organised through teachers. The teachers sent parent questionnaires via the children to the parents, and the parents returned them in a sealed envelope to the teachers. The children filled in their own questionnaires in the classroom.

\section{Bullying}

At baseline, three informants were utilised to assess bullying behaviour: the child himself/herself, a parent, and a 
teacher. The children were asked about bullying by giving them three alternatives from which to choose: $1=\mathrm{I}$ do not usually bully other children, 2 = I sometimes bully other children, 3 = I bully other children nearly every day. Furthermore, children were asked about being victims of bullying: $1=$ Other children do not usually bully me, $2=$ Other children sometimes bully me, 3 = Other children bully me nearly every day. Similar questions focusing on bullying and victimization were included in parent and teacher questionnaires, with probe and response items worded as follows: The child bullies other children/is a victim of bullying: $1=$ Doesn't apply, 2 = Applies somewhat, $3=$ Certainly applies. In the present study, only two categories were used for the frequency of bullying/victimization and therefore options 2 and 3 were pooled together in all of the analyses. The respondents at age eight were hence classified as never bully or ever bully, never victim or ever victim and the combinations of these alternatives. The extent of bullying and victimization was investigated both by combining the information obtained from the child, parent and teacher, and by using the informant-specific variables. When the combined variables were used, bullying or victimization was considered to exist if it was reported by at least one informant.

\section{Confounding variables}

The confounding variables used in this study were childhood psychopathology, family structure, and age and educational level of the girl's mothers. The psychopathology score was based on the sum score of the Rutter Parent and Teacher Scales [34,35]. The bullying/victimization items were removed from the sum scale. The Rutter scales comprise conduct, attention and emotional subscales. The psychopathology variable was used as continuous. As regards factors pertaining to family, the intact family structure was defined as living with two biological parents. Any other kind of family arrangement was referred to as a non-intact family structure. The parents' educational level was studied through the mother's completion of upper secondary school only, due to the low number of reports from fathers. Not completing upper secondary school was considered as having low educational level. The girls' mothers who were born in the year 1961 or later were referred to as young mothers and those born in 1960 or earlier were referred to as old mothers.

\section{$\underline{\text { The outcome }}$}

Information concering deliveries in 1994-2000 was based on the Finnish Hospital Discharge Register. The register is maintained by the National Institute for Health and Welfare and is one of its most frequently used registers for research purposes [36]. It covers the diagnoses and the days of admission and discharge in all public and private inpatient care units in Finland. Less than $0.5 \%$ of Finnish babies are born outside hospital [37], and less than $0.5 \%$ of mothers leave 
the hospital the same day they give birth [38], which means that more than $99 \%$ of births should be included in the Hospital Discharge Register. The coverage and quality of the register is generally considered to be good [36]. A study on the reliability of the register showed that $99 \%$ of the diagnoses indicating a delivery matched those in the patient records [39]. In the present study, the the ICD10 diagnostic codes indicating a delivery represented the information collected. Information pertaining to the mothers' age at birth was only available with an accuracy of one year. Teenage mothers were defined as those who were younger than 20 when they gave birth.

\section{$\underline{\text { Statistical Analysis }}$}

Associations between childhood variables and becoming a teenage mother were quantified by calculating odds ratios (OR) with $95 \%$ confidence intervals (CI) using logistic regression analysis. The odds ratios for continuous variables (related to child psychopathology) were calculated for the change in one standard deviation unit (SD). The reference group was defined as girls who had not given birth under the age of 20. Both single predictor and multipredictor analyses were conducted with combined bullying variables, including information from all informants, and with informant-specific bullying variables. Statistical computations were conducted with the SAS System for Windows, release $9.2 / 2008$.

\section{$\underline{\text { Results }}$}

In the total sample, $51.8 \%$ of girls had never bullied others nor been bullied. The proportion of those who had never bullied others, but had sometimes or frequently been victims of bullying according to at least one informant, was 24.1 $\%$, whereas $8.1 \%$ had sometimes or frequently bullied others, but never been victims themselves. Further, $16.0 \%$ of girls were classified as bully-victims since they had at least sometimes bullied others as well as been bullied. The number of teenage mothers in the total sample was $128(4.8 \%)$.

The odds ratios for the risk of becoming a teenage mother when the combined bullying variables were used are indicated in Table 1. Both bullies and victims had a higher odds of becoming a teenage mother compared with those who were never victims nor bullies. In the single predictor analysis the odds ratio was highest (2.7) among bullyvictims, but when the three groups were compared with each other instead of being compared with the group "never 
bully - never victim", no statistically significant differences were found. The associations remained significant when adjusted for the mother's age and educational level and family structure (Model 1 in Table 1), these associations remained significant. However, when also adjusted for childhood psychopathology (Model 2 in Table 1), the associations remained significant for bullies and bully-victims, but not for pure victims.

When the reports of bullying from the parents, teachers and girls themselves were analysed separately, a statistically significant association was found between each informant's report of bullying others and becoming a teenage mother. Parent and teacher reports but not girl's self-report of victimization were associated with becoming a teenage mother. When the reports were included in the two multipredictor models, one for bullying and the other for victimization, it was evidnet that the parents', teachers' and children's report of bullying and victimization were all associated with becoming a teenage mother independently of each other (Table 2).

\section{$\underline{\text { Discussion }}$}

It is known from previous research that girls who suffer from psychiatric problems or have a certain type of family background are more likely to become teenage mothers. What this study adds is that bullying in childhood is also associated with becoming a teenage mother. This information contributes to a wider understanding of girls' peer relationships, psychopathology and sexual behaviour.

The first finding of this study indicated that female bullies are at risk of becoming teenage mothers, regardless of the baseline psychopathology or previously known family-related risk factors. Considering that psychiatric problems are known to increase the risk of teenage pregnancy, and to be related to bullying, it is interesting that bullying and psychopathology seem to be independent risk factors. This may suggest that at least the female bullies who become teenage mothers, use more subtle and less physically aggressive ways of bullying and are not necessarily categorised as having conduct problems or other psychiatric symptoms. When adjusted for psychopathology, the association between bullying behaviour and becoming a teenage mother seemed to be stronger for bullies than for bully-victims. This may reflect a more severe psychological disturbance among bully-victims [40]. 
There are several ways to approach the association between bullying and becoming a teenage mother. Bullying can be considered as a form of interpersonal aggression. Girls' aggression is more often indirect or relational in contrast to overt physical aggression $[41,42]$. Although relational aggression is no less harmful to its victims $[41,43]$, it may still be better accepted among peer group members [44]. Girls' use of indirect aggression has been shown to correlate negatively with their rejection among boys in particular [44]. The social position and quality of peer relations may also be reflected in bullies' romantic relationships and their sexual behaviour. Bullies seem to start dating earlier and participate in more advanced forms of dating, but their relationships also tend to be less supportive and more violent relationships [45]. It may be that girls who bully others have learnt that aggression is a way of forming interpersonal relations. This corresponds to research indicating that children's insecure attachment is linked to behaviour problems [46,47]. Research has suggested that both bullies [48] and pregnant teenagers [12] have experienced family dysfunction more often than their non-bullying or non-pregnant peers. It is also possible that bullies are more willing to have a child than their non-bullying peers. A study by Connolly et al. [45], suggested that bullies are prepared to engage in undesirable activities to keep their partners and consider their relationships very important. The desire for intimacy may also be related to positive attitudes toward parenthood. Unfortunately, differentiating between girls whose baby was intended and wanted, and those for whom motherhood was unplanned or even unwanted was not possible in the present study. Further studies would also be needed to examine if bullies learn different modes of parenting behaviour as compared to their non-bullying peers.

The second finding of this study indicated that victimization at age eight alone is not associated with becoming a teenage mother, after controlling for childhood psychopathology. This may indicate that the association between childhood victimization and later becoming a teenage mother is a function of psychopathology rather than the victimization per se. One possible explanation would be that victims suffer from depression or other psychiatric problems [27,49], and they may have a tendency to use rapidly initiated sexual activity with multiple partners as a means of coping with feelings of depression and emptiness [50]. To be able to feel some control and confidence, the victims, who deal with a situation over which they have no control (peer victimization), put themselves in a controlled situation (pregnancy/being a mother). In other cases, the pregnancy may be a result of sexual victimization, which is a specific extreme form of victimization, frequently neglected in the bullying literature. In these cases, the childhood "no control" situation is repeated in adolescence. This option is in line with previous studies indicating that childhood sexual abuse has been found to place girls at increased risk of subsequent adolescent pregnancy [51]. 
The third finding of this study involved the fact that reports of bullying and victimization from different informants were independently associated with becoming a teenage mother. Cross-informant agreement about bullying behaviour is typically low [52] and therefore different girls may be considered as bullies or victims by their teachers, parents and themselves. Peer reports of bullying behaviour were not available in the present study, but others suggest that it correlates well with self-report $[41,43]$.

There are several strengths in the design of this study. The sample was relatively large and nationally representative, the baseline assessment was founded on multiple informants and conducted as early as at the age of eight, the attrition rate was low and the outcome measure was based on reliable register data. However, there are limitations particularly concerning the data collected in childhood. The information on bullying behaviour was based on only a few questions. The type of bullying was not specified, and the duration of bullying was not included; nor was there a survey of whether the bullies in the sample bullied girls or boys, or whether the victims in the sample were bullied by girls or boys. In addition, only two categories were used for the frequency of bullying and victimization. However, a post-hoc analysis showed that girls who bullied/were victimized sometimes and girls who bullied/were victimized frequently did not significantly differ in their risk of becoming a teenage mother. The small amount of observations, however, posed a limitation on the analysis for bullies, i.e. there were only three teenage mothers, who had bullied others frequently. Finally, developmental reasoning was limited because both bullying and psychopathology were assessed only in childhood, and the exact timing of childbirth was not known.

\section{$\underline{\text { Conclusions }}$}

The association between bullying in childhood and becoming a mother in adolescence is a new finding, which may have practical implications in sexual health education and teenage pregnancy prevention, especially in school settings. School counsellors should be urged to openly discuss involvement in childhood bullying behaviour and target those involved for teenage pregnancy prevention. It is not known whether the prevention of bullying has an impact on the incidence of teenage pregnancies. It has been suggested that improving the school ethos might reduce teenage pregnancy levels, but no strong evidence is yet available [53]. Further studies focusing on possible pathways between bullying and sexual behaviour are needed. Particular attention should be paid to the different types of problems in peer relations, their association with sexual development and the quality of intimate relationships. 


\section{Acknowledgements}

Dr. Lehti received a grant from the Finnish Foundation for Pediatric Research (Lastentautien tutkimussäätiö).

\section{Conflict of interest}

Dr. Niemelä has consulted Pfizer and been invited as a lecturer by AstraZeneca. These companies have no role in the production of this manuscript. The other authors have no potential conflicts of interest to disclose.

\section{$\underline{\text { References }}$}

1. Moffitt TE, E-Risk Study Team (2002) Teen-aged mothers in contemporary Britain. J Child Psychol Psychiatry 43:727-42

2. Maughan B, Lindelow M (1997) Secular change in psychosocial risks: the case of teenage motherhood. Psychol Med 27:1129-44

3. Schmidt RM, Wiemann CM, Rickert VI, Smith EO (2006) Moderate to severe depressive symptoms among adolescent mothers followed four years postpartum. J Adolesc Health 38:712-8

4. Henretta JC, Grundy EM, Okell LC, Wadsworth ME (2008) Early motherhood and mental health in midlife: a study of British and American cohorts. Aging Ment Health 12:605-14

5. De Genna NM, Cornelius MD, Donovan JE (2009) Risk factors for young adult substance use among women who were teenage mothers. Addict Behav 34:463-70

6. Shaw M, Lawlor DA, Najman JM (2006) Teenage children of teenage mothers: psychological, behavioural and health outcomes from an Australian prospective longitudinal study. Soc Sci Med 62:2526-39

7. Fergusson DM, Woodward LJ (1999) Maternal age and educational and psychosocial outcomes in early adulthood. J Child Psychol Psychiatry 40:479-89

8. Ekeus C, Olausson PO, Hjern A (2006) Psychiatric morbidity is related to parental age: a national cohort study. Psychol Med 36:269-76

9. Woodward LJ, Fergusson DM, Horwood J (2001) Risk factors and life processes associated with teenage pregnancy. Results of a prospective study from birth to 20 years. J Marriage Fam 63:1170-84

10. Meade CS, Kershaw TS, Ickovics JR (2008) The intergenerational cycle of teenage motherhood: an ecological approach. Health Psychol 27:419-29 
11. Imamura M, Tucker J, Hannaford P, da Silva MO, Astin M, Wyness L, Bloemenkamp KW, Jahn A, Karro H, Olsen J, Temmerman M, REPROSTAT 2 group (2007) Factors associated with teenage pregnancy in the European Union countries: a systematic review. Eur J Public Health 17:630-6

12. Miller BC, Benson B, Galbraith KA (2001) Family relationships and adolescent pregnancy risk: a research synthesis. Dev Rev 21:1-38

13. Fergusson DM, Woodward LJ (2000) Educational, psychosocial, and sexual outcomes of girls with conduct problems in early adolescence. J Child Psychol Psychiatry 41:779-92

14. Colman I, Murray J, Abbott RA, Maughan B, Kuh D, Croudace TJ, Jones PB (2009) Outcomes of conduct problems in adolescence: 40 year follow-up of national cohort. BMJ 338:a2981

15. Woodward LJ, Fergusson DM (1999) Early conduct problems and later risk of teenage pregnancy in girls. Dev Psychopathol 11:127-41

16. Woodward LJ, Horwood LJ, Fergusson DM (2001) Teenage pregnancy: cause for concern. N Z Med J 114:301-3

17. Miller-Johnson S, Winn DM, Coie J, Maumary-Gremaud A, Hyman C, Terry R, Lochman J (1999) Motherhood during the teen years: a developmental perspective on risk factors for childbearing. Dev Psychopathol 11:85-100

18. Bardone AM, Moffitt TE, Caspi A, Dickson N, Stanton WR, Silva PA (1998) Adult physical health outcomes of adolescent girls with conduct disorder, depression, and anxiety. J Am Acad Child Adolesc Psychiatry 37:594-601

19. Jaffee SR (2002) Pathways to adversity in young adulthood among early childbearers. J Fam Psychol 16:38-49

20. Underwood MK, Kupersmidt JB, Coie JD (1996) Childhood peer sociometric status and aggression as predictors of adolescent childbearing. J Res Adolescence 6:201-23

21. Olweus D (1993) Victimization by Peers: Antecedents and Long Term Outcomes. In Rubin KH, Asendorf JB (ed) Social Withdrawal, Inhibition, and Shyness in Childhood, Hillsdale, NJ: Lawrence Erlbaum Associates, pp. 315-41

22. Forero R, McLellan L, Rissel C, Bauman A (1999) Bullying behaviour and psychosocial health among school students in New South Wales, Australia: cross sectional survey. BMJ 319:344-8

23. Dake JA, Price JH, Telljohann SK (2003) The nature and extent of bullying at school. J Sch Health 73:173-80

24. Kumpulainen K, Rasanen E (2000) Children involved in bullying at elementary school age: their psychiatric symptoms and deviance in adolescence. An epidemiological sample. Child Abuse Negl 24:1567-77

25. Wolke D, Woods S, Bloomfield L, Karstadt L (2001) Bullying involvement in primary school and common health problems. Arch Dis Child 85:197-201

26. Nansel TR, Overpeck M, Pilla RS, Ruan WJ, Simons-Morton B, Scheidt P (2001) Bullying behaviors among US youth: prevalence and association with psychosocial adjustment. JAMA 285:2094-100 
27. Hawker DS, Boulton MJ (2000) Twenty years' research on peer victimization and psychosocial maladjustment: a meta-analytic review of cross-sectional studies. J Child Psychol Psychiatry 41:441-55

28. Arseneault L, Walsh E, Trzesniewski K, Newcombe R, Caspi A, Moffitt TE (2006) Bullying victimization uniquely contributes to adjustment problems in young children: a nationally representative cohort study. Pediatrics 118:130-8

29. Egan SK, Perry DG. (1998) Does low self-regard invite victimization? Dev Psychol 34:299-309

30. Nansel TR, Overpeck MD, Haynie DL, Ruan WJ, Scheidt PC (2003) Relationships between bullying and violence among US youth. Arch Pediatr Adolesc Med 157:348-53

31. Kim YS, Leventhal BL, Koh YJ, Hubbard A, Boyce WT (2006) School bullying and youth violence: causes or consequences of psychopathologic behavior? Arch Gen Psychiatry 63:1035-41

32. Sourander A, Jensen P, Ronning JA, Elonheimo H, Niemelä S, Helenius H, Kumpulainen K, Piha J, Tamminen T, Moilanen I, Almqvist F (2007) Childhood bullies and victims and their risk of criminality in late adolescence: the Finnish From a Boy to a Man study. Arch Pediatr Adolesc Med 161:546-52

33. Almqvist F, Ikäheimo K, Kumpulainen K, Tuompo-Johansson E, Linna SL, Puura K, Moilanen I, Räsänen E, Tamminen T, Piha J (1999) Design and subjects of a Finnish epidemiological study on psychiatric disorders in childhood. Eur Child Adolesc Psychiatry 8 Suppl 4:3-6

34. Rutter M. A children's behaviour questionnaire for completion by teachers: preliminary findings (1967) J Child Psychol Psychiatry 8:1-11

35. Rutter M, Tizard J, Whitmore K (ed) (1970) Education, Health and Behaviour, London: Longman

36. Gissler M, Haukka J (2004) Finnish health and social welfare registers in epidemiological research. Norsk epidemiologi 14:113-20

37. Vuori E, Gissler M (2008) Newborn children 2006. Statistical summary 10/2008. National Research and Development Centre for Welfare and Health

38. Vuori E, Gissler M (2008) Parturients, births and newborns 2007. Statistical summary 30/2008. National Research and Development Centre for Welfare and Health

39. Aro S, Koskinen R, Keskimaki I (1990) Reliability of hospital discharge data concerning diagnosis, treatments and accidents. Duodecim 106:1443-50

40. Kumpulainen K, Räsänen E, Henttonen I, Almqvist F, Kresanov K, Linna SL, Moilanen I, Piha J, Puura K, Tamminen T (1998) Bullying and psychiatric symptoms among elementary school-age children. Child Abuse Negl $22: 705-17$ 
41. Prinstein MJ, Boergers J, Vernberg EM (2001) Overt and relational aggression in adolescents: social-psychological adjustment of aggressors and victims. J Clin Child Psychol 30:479-91

42. Crick NR, Grotpeter JK (1995) Relational aggression, gender, and social-psychological adjustment. Child Dev $66: 710-22$

43. Crick NR, Bigbee MA (1998) Relational and overt forms of peer victimization: a multi-informant approach. J Consult Clin Psychol 66:337-47

44. Salmivalli C, Kaukiainen A, Lagerspetz K (2000) Aggression and sociometric status among peers: do gender and type of aggression matter? Scand J Psychol 41:17-24

45. Connolly J, Pepler D, Craig W, Taradash A (2000) Dating experiences of bullies in early adolescence. Child Maltreat 5:299-310

46. Greenberg MT, Speltz ML, DeKlyen M, Jones K (2001) Correlates of clinic referral for early conduct problems: variable- and person-oriented approaches. Dev Psychopathol 13:255-76

47. Guttmann-Steinmetz S, Crowell JA (2006) Attachment and externalizing disorders: a developmental psychopathology perspective. J Am Acad Child Adolesc Psychiatry 45:440-51

48. Shields A, Cicchetti D (2001) Parental maltreatment and emotion dysregulation as risk factors for bullying and victimization in middle childhood. J Clin Child Psychol 30:349-63

49. Klomek AB, Marrocco F, Kleinman M, Schonfeld IS, Gould MS (2007) Bullying, depression, and suicidality in adolescents. J Am Acad Child Adolesc Psychiatry 46:40-9

50. Becker-lausen E, Rickel AU (1995) Integration of teen pregnancy and child abuse research: identifying mediator variables for pregnancy outcome. J Prim Prev 16:39-53

51. Noll JG, Shenk CE, Putnam KT (2009) Childhood sexual abuse and adolescent pregnancy: a meta-analytic update. J Pediatr Psychol 34:366-78

52. Ronning JA, Sourander A, Kumpulainen K, Tamminen T, Niemelä S, Moilanen I, Helenius H, Piha J, Almqvist F (2009) Cross-informant agreement about bullying and victimization among eight-year-olds: whose information best predicts psychiatric caseness 10-15 years later? Soc Psychiatry Psychiatr Epidemiol 44:15-22

53. Bonell C, Fletcher A, McCambridge J (2007) Improving school ethos may reduce substance misuse and teenage pregnancy. BMJ 334:614-6

Table 1. Results of single and multipredictor logistic regression models with a binary response (birth $<20$ years or not) and combined bullying variables at age eight.

\begin{tabular}{|c|c|c|c|c|}
\hline & \multicolumn{2}{|c|}{ Teenage mothers } & \multirow{2}{*}{ Univariate analysis OR (95\% CI) } & \multirow[t]{2}{*}{ Multivariate ana } \\
\hline & $\mathbf{n}$ & $\%$ & & \\
\hline Never bully nor victim & 1299 & 3.1 & ref & \\
\hline
\end{tabular}




\begin{tabular}{|c|c|c|c|c|}
\hline Ever victim only & 603 & 5.5 & $1.8(1.1-2.9)^{*}$ & $1.8(1.1-2.9)^{*}$ \\
\hline Ever bully only & 204 & 7.4 & $2.5(1.3-4.6)^{* *}$ & $2.4(1.3-4.5)^{* *}$ \\
\hline Ever bully and victim & 401 & 8.0 & $2.7(1.7-4.4)^{* * *}$ & $2.4(1.4-3.9)^{* * *}$ \\
\hline
\end{tabular}

Multivariate model 1 included pooled reports of bullying behaviour, mother's educational level, mother's age and family structure. Multivariate model 2 included pooled reports of bullying behaviour, mother's educational level, mother's age, family structure and childhood psychopathology (Rutter total score, parents' and teachers' report combined). The other three groups were compared with the "never bully or victim" group. OR $=$ odds ratio, $\mathrm{CI}=$ confidence interval, $* \mathrm{p}<0.05$, $* * \mathrm{p}<0.01, * * * \mathrm{p}<0.001$ 
Table 2. Results of multipredictor logistic regression models with a binary response (birth $<20$ years or not) and informant-specific bullying variables at age eight.

\begin{tabular}{|c|c|c|c|}
\hline & \multicolumn{2}{|c|}{ Teenage mothers } & \multirow[t]{2}{*}{$\begin{array}{l}\text { Multipredictor analysis OR (95\% } \\
\text { CI) }\end{array}$} \\
\hline & $\mathbf{n}$ & $\%$ & \\
\hline Parent report of bullying & & & Model 1 \\
\hline Never bully & 2315 & 4.3 & \\
\hline Ever bully & 270 & 8.2 & $2.2(1.3-3.9)^{* *}$ \\
\hline \multicolumn{4}{|l|}{ Teacher report of bullying } \\
\hline Never bully & 2440 & 4.3 & \\
\hline Ever bully & 173 & 11.6 & $2.2(1.4-3.4) * * *$ \\
\hline \multicolumn{4}{|l|}{ Child report of bullying } \\
\hline Never bully & 2261 & 4.4 & \\
\hline \multirow[t]{2}{*}{ Ever bully } & 325 & 8.0 & $1.8(1.1-2.9)^{*}$ \\
\hline & & & Model 2 \\
\hline \multicolumn{4}{|c|}{ Parent report of victimization } \\
\hline Never victim & 2139 & 4.0 & \\
\hline Ever victim & 441 & 8.2 & $1.6(1.02-2.8)^{*}$ \\
\hline \multicolumn{4}{|c|}{ Teacher report of victimization } \\
\hline Never victim & 2464 & 4.3 & \\
\hline Ever victim & 150 & 13.3 & $2.2(1.3-3.9)^{* *}$ \\
\hline \multicolumn{4}{|c|}{ Child report of victimization } \\
\hline Never victim & 1836 & 4.7 & \\
\hline Ever victim & 743 & 5.3 & $1.7(1.1-2.8)^{*}$ \\
\hline
\end{tabular}

Model 1 included information about bullying from three different informants. Model 2 included information about victimization from three different informants. $\mathrm{OR}=$ odds ratio, $\mathrm{CI}=$ confidence interval, $* \mathrm{p}<0.05, * * \mathrm{p}<0.01, * * * \mathrm{p}<0.001$ 